\title{
MENGEDUKASI MASYARAKAT AKAN PENTINGNYA LIMBAH INDUSTRI GARMEN PADA KAMPUNG CANGKUANG MENJADI PRODUK UNGGULAN DESA BESERTA PEMASARANNYA
}

\author{
Leni Cahyani ${ }^{1)}$, Nellyaningsih' ${ }^{2)}$, Rahmat Hidayat ${ }^{3)}$, Sampurno Wibowo ${ }^{4}$, \\ Agus Maolana Hidayat ${ }^{5)}$, Donny Trihandono( ${ }^{6}$, Didit Endriawan ${ }^{7)}$ \\ Universitas Telkom ${ }^{1,2,3)}$ \\ Universitas Telkom ${ }^{4,5)}$ \\ Universitas Telkom ${ }^{6,7)}$ \\ lenicahyani@tass.telkomuniversity.ac.id
}

\begin{abstract}
ABSTRAK
Desa Cangkuang merupakan salah satu wilayah yang ada di kawasan industri di daerah Rancaekek, Kabupaten Bandung, Jawa Barat. Desa Cangkuang diapit oleh pabrik yang bergerak di cotton mill, manufacture (umumnya pemintalan benang hingga pakaian), dan food production. Kawasan industri di Rancaekek wajib memperhatikan aspek lingkungan, pasalnya kawasan perbatasan antara Kabupaten Bandung dengan Sumedang tersebut menghasilkan limbah cair B3 (Bahan Berbahaya dan Beracun) yang datang dari industri tekstil, tenun, dan garmen. Infrastruktur pengelolaan limbah terpadu dirasa sangat mendesak dibangun di setiap kawasan industri. Setiap industri juga harus didorong menguasai manajemen pengelolaan limbah. Tentunya hal ini memerlukan komitmen semua pihak untuk segera memulihkan kondisi lingkungan disana. Sehingga dalam membangun industri berwawasan lingkungan dan berkelanjutan bukan hanya sekedar slogan, tapi memang membutuhkan realisasi. Dengan keadaan pandemi covid sekarang ini metode yang digunakan berupa serah terima materi pelatihan kepada perwakilan desa cangkuang untuk didistribusikan kepada masyarakat pengrajin melalui karang taruna, penyerahan website untuk penjualan secara online dilakukan kepada perwakilan kepala desa.
\end{abstract}

Kata kunci: Pengolahan Limbah, Inovasi Daur Ulang, Penanggulangan Kemiskinan.

\begin{abstract}
Cangkuang Village is one of the areas in the industrial area in Rancaekek, Bandung Regency, West Java. Cangkuang village is flanked by factories that operate in cotton mills, manufactures (generally spinning yarn to clothing), and food production. The industrial estate in Rancaekek must pay attention to environmental aspects, because the border area between Bandung Regency and Sumedang produces B3 (Hazardous and Toxic) liquid waste that comes from the textile, weaving and garment industries. Integrated waste management infrastructure is considered very urgent to be built in every industrial area. Each industry must also be encouraged to master the management of waste management. Of course this requires the commitment of all parties to immediately restore the environmental conditions there. So that in building an environmentally friendly and sustainable industry it is not just a slogan, but it does require realization. With the current condition of the Covid pandemic, the method used in the form of handover of training materials to representatives of the Cangkuang village to be distributed to the artisans through the Youth Organization, website submission for online sales is carried out to representatives of the village head.
\end{abstract}

Keywords: Waste Management, Recycling Innovations, Poverty Alleviation.

\section{PENDAHULUAN}

Di tengah gencarnya pemerintah menggalakkan sosialisasi Citarum Harum yang bebas dari sampah dan limbah yang akan merusak ekosistem sungai serta mencegah banjir. Dari hasil survei dan informasi yang didapat dari pihak Kecamatan maupun penduduk setempat, masalah banjir atau genangan yang terjadi pada masing-masing lokasi mempunyai karateristik penyebab dan dampak yang berbeda-beda. Banyaknya 
bangunan-bangunan di pinggir saluran dan masih adanya sampah di saluran atau selokan merupakan faktor utama yang menyebabkan terjadinya penyempitan dan pendangkalan saluran yang dapat mengakibatkan berkurangnya daya tampung saluran. Lebih jelasnya kondisi saluran drainase yang sering menyebabkan banjir.

Secara umum kemungkinan terjadinya banjir/genangan sangatlah besar karena dari ciri-ciri topografis alam yang tidak memungkinkan pengaliran air hujan secara cepat. Oleh karena itu, timbul masalah pada saluran-saluran di sepanjang jalan karena belum adanya saluran drainase yang terhubung secara utuh, yang antara lain penyebabnya adalah kapasitas saluran tidak memadai akibat penyempitan oleh sampah dan endapan/lumpur serta terjadinya sumbatan saluran yang sempit ataupun karena faktor lain (sampah, tumbuhtumbuhan) dan banyaknya bangunan di sepanjang sempadan saluran.

Dilihat dari kedudukan geografis kota Rancaekek berada pada jalur lintasan jalan regional yang menghubungkan kota bandung dengan kota-kota lain yang berada di sebelah timur kota Bandung seperti Garut, Tasikmalaya, Ciamis, serta berada dintara pusat-pusat kegiatan kota Bandung, kawasan pendidikan Jatinangor, serta kawasan Industri. Desa Cangkuang merupakan salah satu wilayah yang ada di kawasan industri di daerah Rancaekek, Kabupaten Bandung, Jawa Barat. Desa Cangkuang diapit oleh pabrik yang bergerak di cotton mill, manufacture (umumnya pemintalan benang hingga pakaian), dan food production.

Banyaknya pabrik yang
berbahan baku benang atau kain,

mengakibatkan adanya tumpukan limbah benang atau kain. Dimana ada yang dikumpulkan untuk dijual kepada pengepul, dijual kembali kepada pabrik garmen lain yang membutuhkan potongan majun sebagai bahan baku usahanya dan sebagian dijual lagi kepada masyarakat dan sebagian dibiarkan menumpuk sebagai limbah yang tidak dimanfaatkan. Daur ulang adalah salah satu strategi pengelolaan sampah padat yang dianggap sudah tidak memiliki nilai ekonomis yang terdiri atas kegiatan pemilahan, pengumpulan, pemrosesan, pendistribusian dan pembuatan produk/material bekas pakai menjadi produk baru. Produk baru tersebut pada umumnya memiliki kualitas yang lebih rendah karena sudah kehilangan sebagian karakteristik bahannya.

Pemanfaatan limbah kain dan benang telah dilakukan masyarakat Desa Cangkuang, yaitu dengan melakukan daur ulang dengan menjadikan limbah tersebut menjadi keset, tas, selimut, dan sarung tangan. Pemasarannya tidak sulit karena mempunyai harga yang murah dan terdapat banyak bandar/pengepul yang siap menampung untuk memasarkannya. Keset berbahan baku limbah garmen memiliki kekuatan dan penampilan yang tidak kalah bersaing dengan yang berbahan baku nonlimbah. Bahan bakunya berupa pinggiran kain yang sudah dibuang oleh industri garmen dan disebut tali. Tali yang sudah terkumpul dan dipisah menurut jenis warna dan jenis kainnya kemudian diproses/tenun dengan menggunakan alat tenun yang disebut Tustel. Untuk memberi ikatannya digunakan bahan yang disebut Lusi. Untuk pekerja yang sudah mahir dapat menghasilkan produk keset sebanyak 1,5 kodi atau sejumlah 30 keset per 
hari atau sekitar 40 kodi per bulan. Pemasaran produk keset tidaklah sulit karena disamping harganya murah juga sudah banyak bandar/pengepul yang siap menampung hasil keset tersebut untuk selanjutnya didistribusikan dan dipasarkan ke seluruh pelosok Indonesia.

Kawasan industri di Rancaekek wajib memperhatikan aspek lingkungan, pasalnya kawasan perbatasan antara Kabupaten Bandung dengan Sumedang tersebut menghasilkan limbah cair B3 (Bahan Berbahaya dan Beracun) yang datang dari industri tekstil, tenun, dan garmen. Infrastruktur pengelolaan limbah terpadu dirasa sangat mendesak dibangun di setiap kawasan industri dimanapun. Setiap industri juga harus didorong menguasai manajemen pengelolaan limbah. Banjir juga kerap terjadi di jalan Rancaekek yang menimbulkan kemacetan yang parah. Tentunya hal ini memerlukan komitmen semua pihak untuk segera memulihkan kondisi lingkungan di sana. Sehingga dalam membangun industri berwawasan lingkungan dan berkelanjutan bukan hanya sekadar slogan, tapi membutuhkan realisasi.

Berdasarkan survei langsung dari objek permasalahan, maka tim dengan kedua mitra memutuskan (justifikasi) maka permasalahan prioritas yang akan dicarikan solusinya, yakni:

a. Penyimpanan bahan baku berupa benang dan kain tidak disimpan dengan baik, sehingga jika terjadi hujan maka bahan baku yang ada menjadi susah untuk didaur ulang.

b. Desa Cangkuang merupakan daerah yang di kawasan industri sehingga banyak pendatang dari berbagai daerah. Selain itu penduduk desa ini banyak yang bekerja sebagai buruh. Hal ini berdampak kepada sedikitnya penduduk yang dapat terlibat dalam kegiatan daur ulang.

c. Terbatasnya ide untuk mengembangkan produk, sehingga produk yang dihasilkan selalu sama dengan kualitas yang standar.

d. Pengelolaan usaha daur ulang masih sederhana, hanya sebatas membuat dan menjual ke pengepul/bandar. Sehingga pengelolaan ini masih belum mempunyai rencana usaha (business plan) yang meliputi segala aspek produksi, modal kerja, laporan keuangan hingga pemasarannya.

e. Permasalahan lain yang lebih penting adalah pemasaran produk terbatas, sehingga keuntungan yang didapatkan masih terbatas atau tidak besar. Sehingga manfaat tersebut tidak begitu dapat dirasakan oleh masyarakat.

\section{METODE PELAKSANAAN}

\subsection{Metode Kegiatan Pengabdian}

Adapun metode pendekatan ini ditetapkan oleh tim untuk mengatasi permasalahan, dan solusi mencapai target luaran yang telah ditetapkan yaitu sebagai berikut.

a. Metode Bimbingan Teknis dan Pendampingan. Pakar/Tim bertindak secara aplikatif untuk mengarahkan, membimbing proses dan tahapan, memberi contoh, kepada masyarakat sasar dalam mengatasi permasalahan dan mencapai target dan luaran masyarakat sasar memiliki pemahaman mengenai kreativitas dalam pengembangan produk, 
memahami dan dapat membuat model, corak, jenis dan kombinasi produk dengan berbagai warna, dapat menghasilkan berbagai jenis produk baru dengan model, corak, dan kombinasi produk sesuai tuntutan pasar, dapat menentukan dan memiliki, serta menghasilkan produk unggulannya, membuat merk produk dan masyarakat sasar memiliki merk produk sendiri.

b. Metode Pendekatan Fasilitasi dan Media. Metode pendekatan ini, ditujukan untuk mempermudah, meringankan, memperlancar, menghubungkan, membuatkan (mendesain), mendapatkan, dan memiliki sesuatu yang dibutuhkan oleh masyarakat sasar. Pendekatan Fasilitasi dan mediasi bagi masyarakat sasar ini digunakan dalam mengatasi permasalahan dan mencapai target dan luaran sebagai berikut:

1) Fasilitasi dan mediasi fasilitasi akses terhadap klien/calon pelanggan dan mediasi kemasyarakat sasaran usaha

2) Membuatkan (mendesain) media promosi Website/Blog, kemasan dan merk bagi masyarakat sasar dan prosedur kerja untuk merealisasikan rencana program PKM.

\subsection{Teknik Pengumpulan Data}

Adapun teknik pengumpulan data yang digunakan dalam memperoleh data dan informasi yang aktual yaitu sebagai berikut:

a. Wawancara. Widodo (2017:74) menjelaskan wawancara sebagai kegiatan tanya jawab untuk memperoleh informasi/data, serta wawancara dilakukan dengan tujuan untuk melengkapi data penelitian yang dilakukan secara langsung dan melakukan percakapan dengan responden.

b. Observasi. Siregar (2017:19) mengemukakan bahwa observasi merupakan kegiatan pengumpulan data dengan melakukan penelitian langsung terhadap kondisi lingkungan objek penelitian yang mendukung kegiatan penelitian, sehingga didapat gambaran secara jelas tentang kondisi objek penelitian tersebut.

c. Survei. Menurut Sugiyono (2015:13), metode survei digunakan untuk mendapatkan data dari tempat tertentu secara alami, tetapi peneliti melakukan perlakuan dalam pengumpulan data, misalnya dengan mengedarkan kuesioner, test, wawancara terstruktur.

\subsection{Teknik Analisis Data}

Adapun metode penelitian yang digunakan yaitu kualitatif deskriptif. Menurut Sugiyono (2015:15-18), metode kualitatif dapat diartikan sebagai metode yang digunakan untuk meneliti pada kondisi objek yang alamiah, dimana peneliti sebagai instrumen kunci. Metode deskriptif merupakan prosedur pemecahan masalah dengan cara menggambarkan objek penelitian pada saat keadaan sekarang berdasarkan fakta-fakta sebagaimana adanya, kemudian dianalisis dan diinterpretasi, bentuknya berupa survei dan studi perkembangan (Siregar, 2017:7-8).

\subsection{Lokasi, Waktu, dan Durasi Kegiatan}

Kegiatan pengabdian kepada masyarakat ini telah dilaksanakan di Desa Cangkuang, Rancaekek, Kabupaten Bandung, Jawa Barat. Adapun durasi kegiatan pengabdian 
ini selama 5 bulan, dengan rincian waktu pelaksanaan sebagai berikut: 20 Oktober 2019, 22 Oktober 2019, 10 November 2019, dan 10-13 Februari 2020

\section{HASIL DAN PEMBAHASAN}

Solusi dan target luaran dari "Pengelolaan Hasil Limbah Industri Kampung Cangkuang menjadi Produk Unggulan Usaha Menengah Kecil (UMKM) dalam Menanggulangi Kemiskinan dengan Teknik Digital Marketing", antara lain sebagai berikut:

a. Memberi alternatif penyimpanan bahan baku berupa benang dan kain. Penyimpanan bahan baku berupa benang dan kain, dapat dilakukan dengan memisahkan antara bahan baku benang dan kain dalam suatu tempat atau gudang. Agar tidak terjadi penumpukan bahan baku maka dilakukan pengaturan periode pembelian bahan baku serta menjalin kerjasama dengan pabrik-pabrik di sekitar Desa Cangkuang.

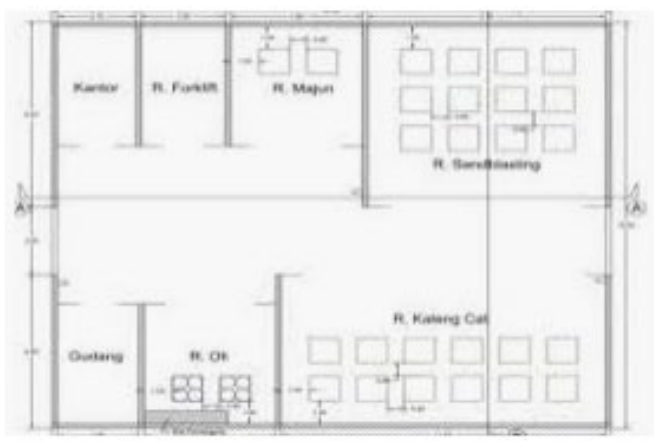

Gambar 1. Desain Gudang Penyimpanan

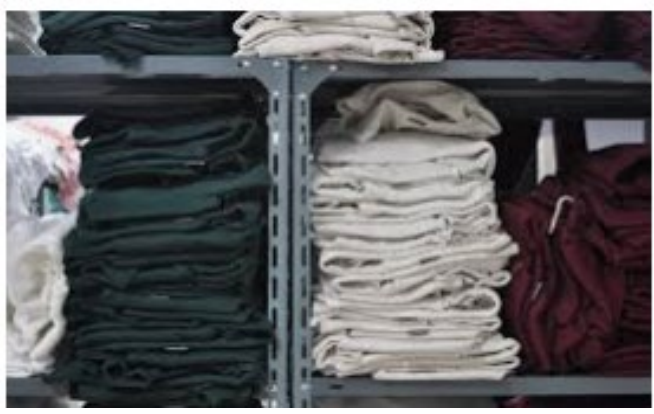

Gambar 2. Desain Rak Penyimpanan Bahan Baku

b. Memberikan pelatihan team building kepada aparatur desa dan karang Taruna Desa Cangkuang, yaitu aktivitas kelompok yang memiliki interaksi tinggi untuk meningkatkan produktivitas karyawan dalam menuntaskan tugas-tugas terutama yang memiliki interdependensi dengan orang lain melalui serangkaian aktivitas yang dirancang secara hati-hati untuk mencapai sasaran yang telah ditentukan sebelumnya. Tujuannya agar antara aparatur desa dan karang taruna Desa Cangkuang dapat bersinergi dengan baik dalam memanjukan Desa Cangkuang, sehingga diharapkan nantinya akan bersama-sama mengelola sumber daya yang efektif, berkomunikasi dan memprioritaskan yang harus dilakukan tanpa benih konflik.

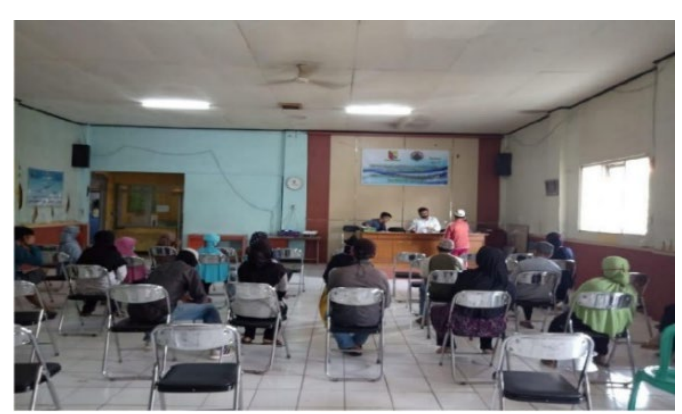

Gambar 3. Pelaksanaan Pelatihan (Tampak Belakang) 


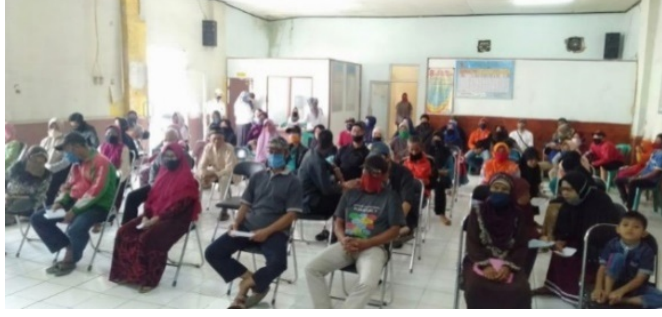

Gambar 4. Pelaksanaan Pelatihan (Tampak Depan)

c. Memberikan pengetahuan dan praktek tentang alternatif pengolahan daur ulang limbah kain dan benang. Produk yang dihasilkan masih terbatas pada keset, tas, selimut, dan sarung tangan. Maka akan dilakukan pelatihan khusus untuk memberikan teknik pengerjaan yang terstandar dengan baik untuk produk yang ada. Alternatif pembuatan produk lain misalnya boneka kecil untuk souvenir, bros untuk kerudung dari kain atau benang. Tentunya alternatif produk yang diberikan harus mempunyai standar yang baik. Kemudian memilihkan produk yang dapat dijadikan unggulan dan ciri khas dari desa Cangkuang, sehingga dapat memberikan nilai lebih bagi desa Cangkuang. Misalnya "Desa penghasil souvenir pernikahan dari kain dan benang".

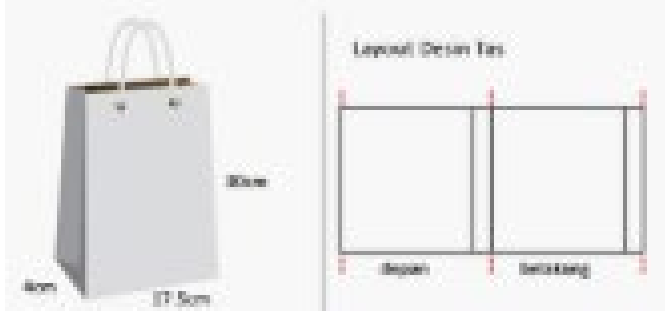

Gambar 5. Desain Packaging

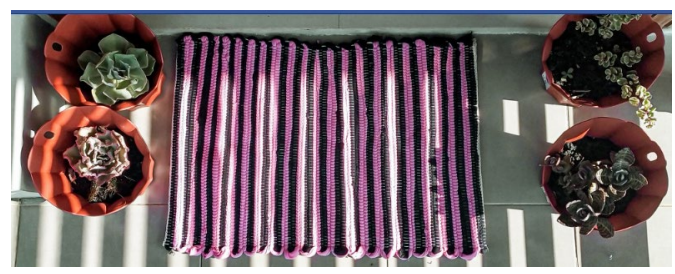

Gambar 6. Produk Daur Ulang Inovatif

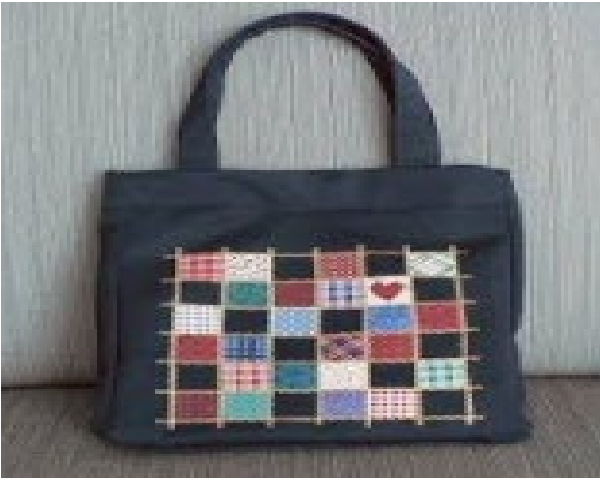

Gambar 7. Contoh Produk Daur Ulang Inovatif

d. Memberikan pengetahuan mengenai rencana usaha (Business Plan). Rencana usaha adalah dokumen tertulis yang disiapkan oleh wirausaha yang menggambarkan semua unsurunsur yang relevan baik internal maupun eksternal mengenai perusahaan untuk memulai suatu usaha. Isinya sering merupakan perencanaan terpadu menyangkut pemasaran, permodalan, manufaktur dan sumber daya manusia. Sedangkan menurut Daft, et al. (2010: 265) business plan adalah dokumen yang merincikan detail-detail bisnis yang disiapkan oleh seorang wirausahawan sebelum membuka sebuah bisnis baru. Berdasarkan pengertian diatas, perencanaan bisnis atau yang lebih dikenal dengan sebutan business plan menyangkut semua aspek produksi mulai dari permodalan sampai pemasaran sehingga usaha yang dijalankan sudah jelas arahnya. Sehingga pelatihan mengenai pembuatan business plan diperlukan oleh Desa Cangkuang. Dimana pelatihan akan meliputi:

1) Pengenalan dan pemahaman aspek yang terdapat di rencana usaha, meliputi aspek pasar, pemasaran, operasi, produksi, 
organisasi dan manajemen, aspek keuangan.

2) Pengenalan dan pemahaman mengenai aspek kekuatan, kelemahan, peluang dan ancaman usaha.

3) Pengenalan dan pemahaman mengenai konsumen.

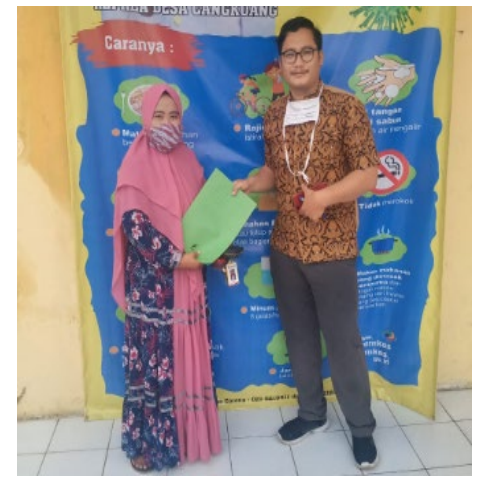

Gambar 8. Pelaksanaan Pelatihan Business Plan

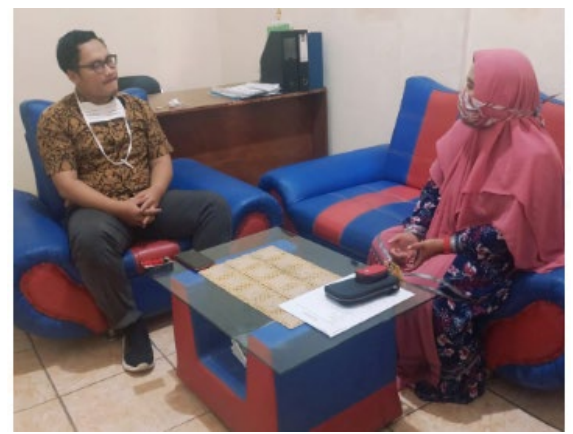

Gambar 9. Koordinasi Sebelum Pelaksanaan Pelatihan

e. Pemasaran produk dengan menggunakan digital marketing, baik dengan pembuatan web, atau promosi di media sosial. Digital marketing adalah praktek marketing yang menggunakan saluran distribusi digital untuk mendapat konsumen dengan cara relevan, personal dan cost-effective (Chaffey, 2015). Adapun kegiatan yang dilakukan yakni.

1) Pembuatan web mengenai produk yang dihasilkan Desa Cangkuang diperlukan sebagai media promosi. Karena web yang saat ini adalah tentang Desa Cangkuang saja. Sehingga diperlukan penanggung jawab dari Desa Cangkuang untuk meng-update data produk terbaru di link https://kerajinancangkuang.ucr aft.site/.

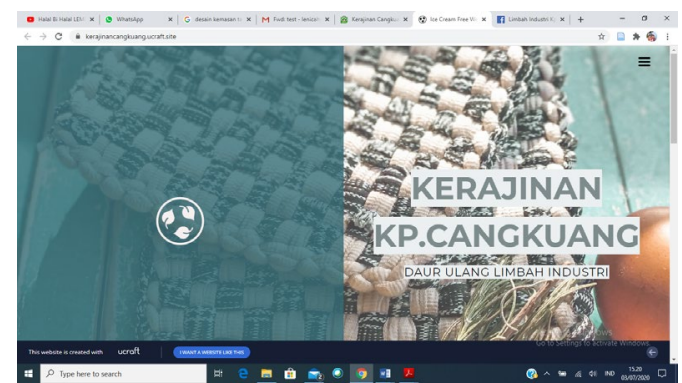

Gambar 10. Website Produk

2) Promosi di media sosial lainnya seperti Instagram, Facebook, Twitter dsb, juga diperlukan dimana data di yang ada di media sosial ini haruslah ada sinkronisasi dengan data yang ada di Web Produk Desa Cangkuang Adapun link-nya adalah sebagai berikut:

a) Instagram:https://www.inst agram.com/kerajinan.cangk uang/

b) Facebook:https://www.face book.com/Limbah-IndustriKp-Cangkuang102857681485342

c) Tokopedia:https://www.tok opedia.com/craftcangkuang

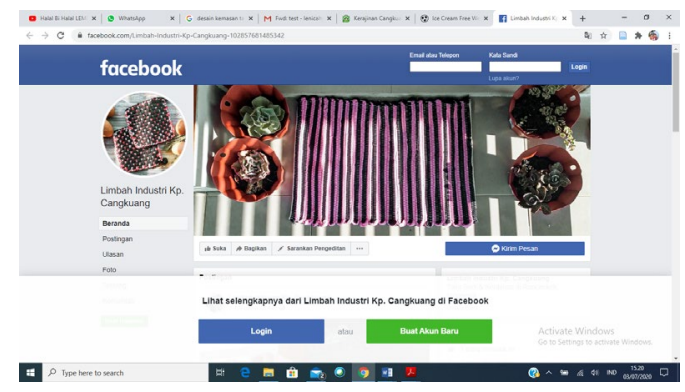

Gambar 11. Halaman Facebook Produk 


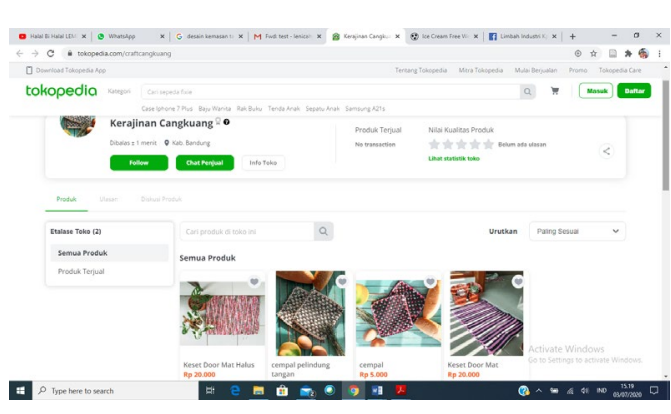

Gambar 12. Halaman Tokopedia Produk

\section{KESIMPULAN}

Para peserta pelatihan yang ratarata para masyarakat yang membuat kerajinan, pengolahan produk dari olahan kain,benang dan limbah industri dimana bergerak dalam memproduksi keset, celemek, kain perca, sarung tangan dan lain-lain, peserta cukup antusias dalam mengikuti pelatihan, kemungkinan hal ini diharapkan bagi mereka dapat meningkatkan wawasan ataupun pengetahuan maupun kemampuannya dalam meningkatkan keterampilan dalam menggunakan media sosial ataupun pemahamannya dalam dunia internet. Hal ini terbukti dari adanya beberapa peserta yang mengajukan pertanyaan berkaitan dengan fasilitas perolehan bantuan modal maupun prosedur penggunaan media sosial dalam usaha meningkatkan produksi dan penjualannya, sehingga mereka berharap dapat memasarkan dan mempopulerkan produk secara lebih luas.

\section{REFERENSI}

Chaffey, D. (2015). Digital Business and E-Commerce Management, Strategy, Implementation, and Practice. England: Pearson Education Limited.

Daft, R. L., Murphy, J., \& Willmott, H. (2010). Organization theory and design. Cengage learning EMEA.

Siregar. S. (2017). Metodologi Penelitian Kuantitatif: Dilengkapi dengan Perbandingan Perhitungan Manual \& SPSS Edisi Pertama Cetakan ke-4. Jakarta: Penerbit Kencana.

Sugiyono. (2015). Metode Penelitian dan Pengembangan: Research and Development/R\&D. Bandung: CV. ALFABETA.

Widodo. (2017). Metodologi Penelitian: Populer \& Praktis. Jakarta: PT. Raja Grafindo Persada. 